\title{
NRAS NP_002515.1:p.G12D
}

National Cancer Institute

\section{Source}

National Cancer Institute. NRAS NP 002515.1:p.G12D. NCI Thesaurus. Code C155671.

A change in the amino acid residue at position 12 in the GT Pase NRas protein where

glycine has been replaced by aspartic acid. 